\title{
Mesophillic Anaerobic Co-Digestion of Horse Dung, Plantain Peel and Egg Sheel at Different Climatic Conditions
}

\section{Cordelia Nnennaya Mama*, Ugwuja Thankgod Oruchukwu, Eze Chidi Ezekiel and Richard Ifechukwu Nnamdi}

\author{
Department of Civil Engineering, University of Nigeria, Nsukka, Enugu State, Nigeria \\ *Corresponding Author: cordelia.mama@unn.edu.ng
}

\begin{abstract}
This study centered on biogas production from locally available animal and kitchen wastes: horse dung $(H D)$, plantain peel (PP) and egg shell (ES) using five 32Litres metallic prototype digesters. The anaerobic digestion was in the ratio of 3:1 of water to waste for all the samples as follows: Sample A was 100\%HD, Sample B; $100 \%$ PP, Sample C; $100 \%$ ES, Sample D; $50 \% H D+50 \% P P$ and Sample E; 60\% HD+30\% ES+10\% $P P$. The retention time was 30 days. Parameters like $p H$, daily biogas production, ambient and slurry temperatures, solar radiation, wind speed, air temperature alongside the physico-chemical properties of wastes were monitored. The cumulative gas production yield was $81.8 \mathrm{~L}, 22.3 \mathrm{~L}, 51.9 \mathrm{~L}$, $109 L$, and $75.2 L$ for samples $A, B, C, D$ and $E$ respectively. The flammable time was $10^{\text {th }}, 13^{\text {th }}, 16^{\text {th }}, 6^{\text {th }}, 10^{\text {th }}$ day for samples $A, B, C, D$ and $E$ respectively. The result revealed that sample D: $50 \% H D+50 \% P P$ gave the highest yield of biogas (109L) and flamed earlier than the other samples (6 days) while sample B: 100\%PP had the lowest yield of biogas $(22.3 \mathrm{~L})$. The results also showed that the sample that had the highest composition of methane in the biogas produced was Sample C: $100 \%$ ES with $90.3995 \%$ while the lowest composition of methane was found in Sample B: $100 \%$ PP to be $79.9963 \%$. The TS and VS were seen to be consistently reducing while TVC and BOD reduced (immediately the microbes got acclimatized to the environment) showing the level of waste treatment achieved during the digestion period of 30 days.
\end{abstract}

Keywords - Anareobic, Co-Digestion, Horse Dung, Plantain Peel, Egg Shell, Climatic Conditions.

Abbreviations: TS=Total Solid, VS=Volatile Solid, BOD=Biochemical Oxygen Demand, $\mathrm{TVC}=$ Total Viable Count

\section{INTRODUCTION}

Today, solid waste management and rising energy cost are two major problems facing the world in the recent days. Secondly the issue of global warming and climate change are strongly receiving public attention and have become a major environmental concern both at national and international level. The increasing concentration of atmospheric greenhouse gases as a result of culpable human activities represents the major cause for this problem (Lassey, 2008).

Possible methods to solve these problems are conversion of the solid wastes into methane gas via anaerobic digester. Anaerobic digestion can be used to treat all types of biodegradable waste, including food waste. It is used to stabilize mixed waste after the removal of recycleable materials. The realistic solution to reduce methane emission from manure storage will be using anaerobic digester in a controlled biogas plant so that methane can be collected as biogas (Külling et al., 2002). In this way atmospheric methane emission from the manure storage could dramatically be decreased. Biogas generated can be utilized for various energy services, such as heat, combined heat, and power. In addition, the biogas can be used as vehicle fuel, after removal of carbon dioxide and hydrogen sulphide in an up grading system (Lantz et al, 2007).

Co-digestion for anaerobic digestion means more than one feedstock is used at a time to produce biogas. Co-digestion is used to improve the methane yield from low yield feedstocks. Care must be taken to select compatible feedstocks that enhance methane yields and avoid materials that may inhibit biogas and methane production. Agricultural feed stocks have successfully been co-digested with restaurant bio wastes, food processing and crop residues (EPA 2012). The quantity, availability, and cost of co-digestion feed stocks are important factors to consider. Other factors to consider include: regulations and 
permitting; digester capacity; mixing of the feed stocks; and nutrient.

Literature contains substantial biogas production from different wastes in the locality. Nwankwo, 2014 did a research on the digestion of plantain peel (PP) and the codigestion of plantain peel with swine droppings (PP-SD) to observe the biogas production ability in a 50litres metal prototype biodigester. The waste (PP and PP-SD) were subjected to anaerobic digestion for a period of 44days. The cumulative biogas yield for the plantain peels alone (PP) was $80.10 \mathrm{dm}^{3}$ while that of plantain peels mixed with swine droppings (PP-SD) was $163.30 \mathrm{~m}^{3}$. The PP-A commenced flammable gas production on the 2 nd day while, PP-SD commenced flammable gas production on the 30th day. The PP-SD had the highest cumulative gas yield though with a slow onset of gas flammability. The overall result indicates that the low gas yield of PP could be significantly enhanced by blending it with swine droppings.

Ezekoye, 2013 carried out a research on Plantain/almond leaves and pig dung used as substrates in anaerobic bio digester for producing biogas by batch operation method within the mesophilic temperature range of 20.0 to $31.0^{\circ} \mathrm{C}$. The study was carried out to compare biogas production potential from plantain/almond leaves and pig dung wastes. The cumulative biogas produced from the plantain/almond leaves was $220.5 \mathrm{~L}$ while the cumulative biogas from the pig dung was $882.5 \mathrm{~L}$. The methane component of gas from pig dung was $70.2 \%$ while that for plantain/almondleaves with algae was $72.7 \%$. The biogas from the almond/plantain leaves became combustible onsixteenth day while the biogas from the pig dung was combustible on fourteenth day. Results showedthat pig dung produced more biogas than the almond/plantain leaves within the same period.

Kusch et al, 2008 conducted an experiments on methanogenesis from horse dung were conducted in laboratory-scale batch reactors in order to determine the substrate performance in a solid-phase digestion process, more specifically in terms of potential energy recovery and suitable process technology. Dung from a horse stable with straw bedding was used. The temperature was kept in the mesophilic range. In the percolation process (with process water sprinkled over the stacked biomass) a proportion of $10-20 \%$ of solid inoculum (pre-digested horse dung) was found to be suitable. Comparative experiments with both percolation and flooding revealed a higher biogas production per volume for the flooded process, as no addition of solid inoculum was necessary. Methane yield from fresh material was similar in both processes: around $170 \mathrm{~L}(\mathrm{~N}) \mathrm{CH}(4)$ per kg VS added was obtained in six-week cycles with untreated material under optimized conditions.
Methane production was increased after chopping the substrate. Pre-aeration resulted in decreased methane production.

Hadin and Eriksson, 2016 stated that horse keeping is of great economic, social and environmental benefit for society, but causes environmental impacts throughout the whole chain from feed production to manure treatment. According to national statistics, the number of horses in Sweden is continually increasing and is currently approximately 360,000 . This in turn leads to increasing amounts of horse manure that have to be managed and treated. Current practices could cause local and global environmental impacts due to poor performance or lack of proper management. Horse manure with its content of nutrients and organic material can however contribute to fertilisation of arable land and recovery of renewable energy following anaerobic digestion. At present anaerobic digestion of horse manure is not a common treatment. In this paper the potential for producing biogas and biofertiliser from horse manure is analysed based on a thorough literature review in combination with mathematical modelling and simulations. Anaerobic digestion was chosen as it has a high degree of resource conservation, both in terms of energy (biogas) and nutrients (digestate). Important factors regarding manure characteristics and operating factors in the biogas plant are identified. Two crucial factors are the type and amount of bedding material used, which has strong implications for feedstock characteristics, and the type of digestion method applied (dry or wet process). Straw and waste paper are identified as the best materials in an energy point of view. While the specific methane yield decreases with a high amount of bedding, the bedding material still makes a positive contribution to the energy balance. Thermophilic digestion increases the methane generation rate and yield, compared with mesophilic digestion, but the total effect is negligible.

Ofili et al., 2010 researched on the quantity of biogas yield fromanaerobic digestion of rabbit waste and swine dung. Thesame volume of digester was used in this experiment toaccurately compare the volume of the biogas yield. Themaximum volume of biogas produced from the 45 litresdigester used was 8.2 litres and 6.8 litres respectively forswine dung and rabbit waste. It was observed that the biogas production from swine dung was greater than that of rabbit waste. These studies focused on anaerobic digestion of one substrate and or co-digestion of only two subtrates. Co- digestion was not extended to more than two wastes. This necessitated embarking on this study. Hence, the aim of this work is to anaerobically co-digest horse dung, 
plantain peel and eggshell.These wastes were chosen in this experiment because they are available within the experimental locations.

\section{MATERIALS AND METHODS}

The study adopted customresponse design. Horse dung was gotten from Obollo-Afor market Udenu L. G. A, egg shell was gotten from Dawuba fast food restaurant behind Ekpo Refectory, University of Nigeria, Nsukka and plantain peels were gotten from Odenigbo Junction Nsukka and some fromOgige market, Nsukka. Metallic model biodigesters (Plate 1) utilized for the study were each of $32.0 \mathrm{~L}$ working volume (fabricated locally at the National Centre for Energy Research and Development, University of Nigeria, Nsukka). Materials such as top loading balance (Camry Emperors Capacity $50 \mathrm{~kg} / 110 \mathrm{Ibs}$ ), plastic water troughs, graduated transparent plastic buckets for measuring daily gas production, the pHep pocket-sized $\mathrm{pH}$ meter (Hanna Instruments), thermometers, pressure gauge, thermoplastic hose pipes, metallic beehive stand and biogas burner fabricated locally for checking gas flammability were used.

\section{Experimental Study}

Table.1: Substrates weight

\begin{tabular}{|l|l|l|l|l|}
\hline DIGESTER & $\begin{array}{l}\text { Horse Dung } \\
(\mathrm{kg})\end{array}$ & $\begin{array}{l}\text { Egg Shell } \\
(\mathrm{kg})\end{array}$ & $\begin{array}{l}\text { Plantain Peel } \\
(\mathrm{kg})\end{array}$ & $\begin{array}{l}\text { Water } \\
(\mathrm{kg})\end{array}$ \\
\hline $\mathrm{A}(100 \% \mathrm{HD})$ & 6 & - & - & 18 \\
\hline $\mathrm{B}(100 \% \mathrm{PP})$ & - & - & 6 & 18 \\
\hline $\mathrm{C}(100 \% \mathrm{ES})$ & - & 6 & - & 18 \\
\hline $\mathrm{D}(50 \% \mathrm{HD}+50 \% \mathrm{PP})$ & 3 & - & 3 & 18 \\
\hline $\mathrm{E}(60 \% \mathrm{HD}+30 \% \mathrm{ES}+10 \% \mathrm{PP})$ & 3.6 & 1.8 & 0.6 & 18 \\
\hline
\end{tabular}

The ratio of water to waste is $3: 1$

\section{DETERMINATION OF PHYSICO-CHEMICAL PROPERTIES}

The methods used in this work to determine the physicochemical properties of the undigested substrates are clearly defined as follows: The Meynell (1982) method was used to determine the: Total solids and Volatile solids while the A.O.A.C method (1990) was used to determine the: Moisture content, Ash content and Crude fibre content. The Pearson (1976) method was used in the determination of the Crude fat content with the use of Soxhlet extraction apparatus. The Micro-Kjedahl method as described in Pearson (1976) was used in the determination of Crude protein content while the method of surface viable count was used in the determination of the Total viable count (Number of living micro-organisms). The Energy content
The fermentation of the blends took place for 30 days at the prevailing ambient mesophillic temperature range of $24^{\circ} \mathrm{C}$ to $34^{\circ} \mathrm{C}$. The ratio of the water to waste in each charging was 3:1. This was based on the moisture content of the organic wastes at the point of charging the biodigesters. Horse dung, plantain peel and egg shell were co-digested to result to the following treatment blends: A $(100 \% \mathrm{HD})$, B $(100 \% \mathrm{PP}), \quad \mathrm{C}(100 \% \mathrm{ES}), \quad \mathrm{D}(50 \% \mathrm{HD}+50 \% \mathrm{PP})$ and $\mathrm{E}$ $(60 \% \mathrm{HD}+30 \% \mathrm{ES}+10 \% \mathrm{PP})$. Table 1 shows details of the blending. Co-digestion is used to increase methane production from low-yielding or difficult to digest materials. The moisture content of the respective wastes determined the waste to water ratios used. Volume of gas produced, ambient and slurry temperatures, relative humidity and wind speed, insolation, $\mathrm{pH}$ and slurry pressure were monitored on daily basis throughout the period of digestion. Flammability check was also carried out on daily basis until the system produced flammable biogas and occasionally till the end of digestion period. The study was carried out at the exhibition ground of National Centre for Energy Research and Development, University of Nigeria, Nsukka. was determined with bomb calorimeter (model XRY-1A, make: Shanghai Changji, China), using A.O.A.C (1990) method).Walkey-Black (1934) method was used to determine the Carbon content while the ambient and slurry temperature was taken daily using a liquid in glass thermometer and the $\mathrm{pH}$ was ascertained using the Hanna instrument $\mathrm{pH}$ meter standardized us ing buffer solutions for $\mathrm{pH}$ 7.0.The pressure of the gas produced in the biogas digesters was measured daily using the sphygmomanometer. This water displacement method was used to determine the biogas volume while the Bacharach (PCA2) gas analyzer was used to determine the gas composition. A locally made gas burner was used to carry out the gas flammability tests. The population of the microbes in each of the treatment cases was determined at 
different times (at charging, flammable, peak of production and end of digestion), during the period of study to monitor the growth of the microbes at the various stages.

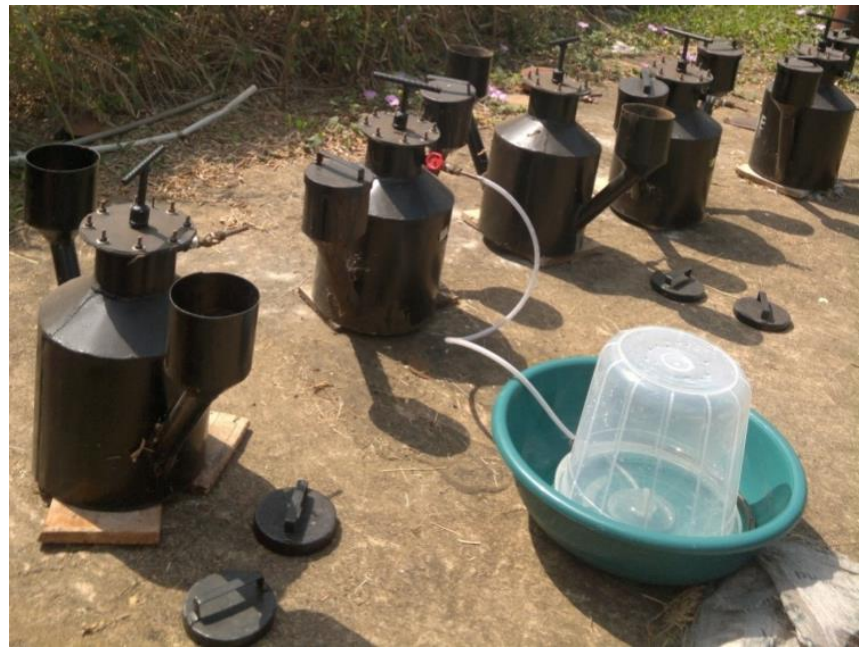

Plate.1: The Anaerobic Biodigesters

\section{Gas Analysis}

The flammable gas compositions from the $100 \% \mathrm{HD}$, $100 \% \mathrm{PP}, 100 \% \mathrm{ES}, 50 \% \mathrm{HD}+50 \% \mathrm{PP}$ and $60 \% \mathrm{HD}+30 \% \mathrm{ES}+10 \% \mathrm{PP}$ were analyzed using BACHARACH (PCA2) Gas Analyzer, made in United States.

\section{Data Analysis}

The data obtained for each of the systems were subjected to analysis using Microsoft Excel XP 2007. Meteorological data were obtained from Centre for Basic Space Science, University of Nigeria, Nsukka.

III. RESULTS AND DISCUSSION

Table 2 shows the physicochemical properties of undigested wastes.

Table.2: Table of the physicochemical properties on the charging day (Day 0)

\begin{tabular}{|l|l|l|l|l|l|}
\hline PARAMETERS & SAMPLE A & SAMPLE B & SAMPLE C & SAMPLE D & SAMPLE E \\
\hline Moisture Content \% & 88.33 & 84.48 & 87.93 & 88.46 & 85.19 \\
\hline Ash Content (\%) & 2.60 & 2.10 & 3.40 & 3.7 & 1.80 \\
\hline Crude Fibre(\%) & 3.80 & 3.40 & 4.10 & 4.60 & 2.51 \\
\hline Crude Fat (\%) & 0.50 & 0.80 & 0.60 & 0.55 & 0.90 \\
\hline Crude Protein (\%) & 1.75 & 1.23 & 1.40 & 0.96 & 2.01 \\
\hline Crude Nitrogen (\%) & 0.175 & 0.196 & 0.224 & 0.154 & 0.18 \\
\hline Carbon Content (\%) & 4.2 & 4.15 & 4.55 & 4.63 & 4.3 \\
\hline Magnesium (ppm) & 0.5710 & 0.5742 & 0.7383 & 0.9286 & 0.7285 \\
\hline Calcium (ppm) & 3.7753 & 1.8090 & 5.1124 & 4.4045 & 3.8539 \\
\hline Volatile Solid (\%) & 8.70 & 11.07 & 8.73 & 7.13 & 11.03 \\
\hline Total Solid (\%) & 10.33 & 12.87 & 9.93 & 8.77 & 13.40 \\
\hline B.O.D (mg/l) & 59.2 & 73.6 & 62.4 & 51.2 & 68.8 \\
\hline Phosphorus (\%) & 0.60 & 0.90 & 1.40 & 1.10 & 1.00 \\
\hline Total Viable Count (TVC) (cfu/ml) & $41.67 \times 10^{5}$ & $56.67 \times 10^{5}$ & $46.67 \times 10^{5}$ & $37.50 \times 10^{5}$ & $50.83 \times 10^{5}$ \\
\hline C/N & 24.0 & 21.174 & 20.313 & 30.065 & 23.889 \\
\hline
\end{tabular}

Table 3 shows the gas compositions for the various substrates.

Table.3: Table of gas composition of the flammable gas from experiment

\begin{tabular}{|c|c|c|c|c|c|c|c|c|}
\hline \multirow[t]{2}{*}{ Sample } & \multirow{2}{*}{$\begin{array}{l}\text { Flammable } \\
\text { Time/Lag } \\
\text { Time (days) }\end{array}$} & \multirow{2}{*}{$\begin{array}{l}\text { Retentio } \\
\text { n Time } \\
\text { (days) }\end{array}$} & \multirow{2}{*}{$\begin{array}{l}\text { Cum vol of } \\
\text { Biogas } \\
\text { (L) }\end{array}$} & \multicolumn{5}{|c|}{ Composition of Biogas (\%) } \\
\hline & & & & $\begin{array}{l}\mathrm{CO}_{2} \\
(\%)\end{array}$ & $\mathrm{CO}$ (ppm) & $\begin{array}{l}\mathrm{CO} \text { converted } \\
\text { to }(\%\end{array}$ & $\begin{array}{l}\mathrm{CH}_{4} \\
(\%)\end{array}$ & Others \\
\hline $\mathrm{A}$ & 10 & 30 & 81.8 & 17 & 10 & $1 \times 10^{-3}$ & 79.999 & 3 \\
\hline $\mathrm{B}$ & 13 & 30 & 22.3 & 17 & 37.3 & $3.7 \times 10^{-4}$ & 79.9963 & 3 \\
\hline $\mathrm{C}$ & 16 & 30 & 51.9 & 6.6 & 5 & $5 \times 10^{-4}$ & 90.3995 & 3 \\
\hline $\mathrm{D}$ & 6 & 30 & 109.0 & 14.4 & 8 & $8 \times 10^{-4}$ & 82.5992 & 3 \\
\hline $\mathrm{E}$ & 10 & 30 & 75.2 & 9.6 & 8 & $8 \times 10^{-4}$ & 87.3992 & 3 \\
\hline
\end{tabular}


Table 4 shows the energy content/ calorific values of the substrates

Table.4: Energy Contents/Calorific Values of substrates

\begin{tabular}{|l|l|}
\hline Egg shell & $13938.63 \mathrm{KJ} / \mathrm{Kg}$ \\
\hline Plantain peel & $20634.86 \mathrm{KJ} / \mathrm{Kg}$ \\
\hline Horse dung & $21351.17 \mathrm{KJ} / \mathrm{Kg}$ \\
\hline
\end{tabular}

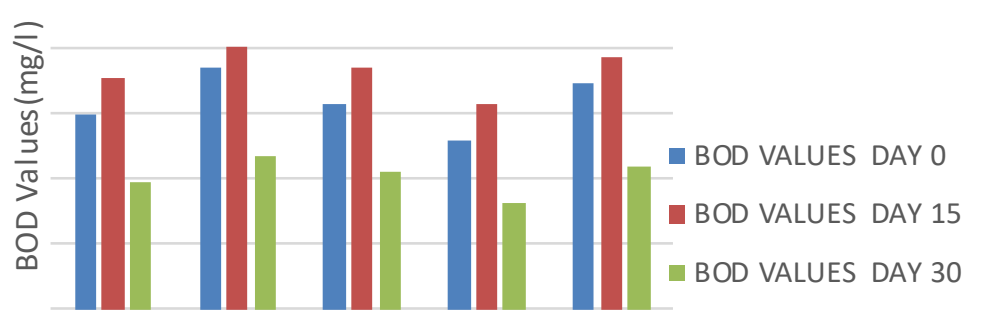

Digester

Fig.1: Weekly BOD Values

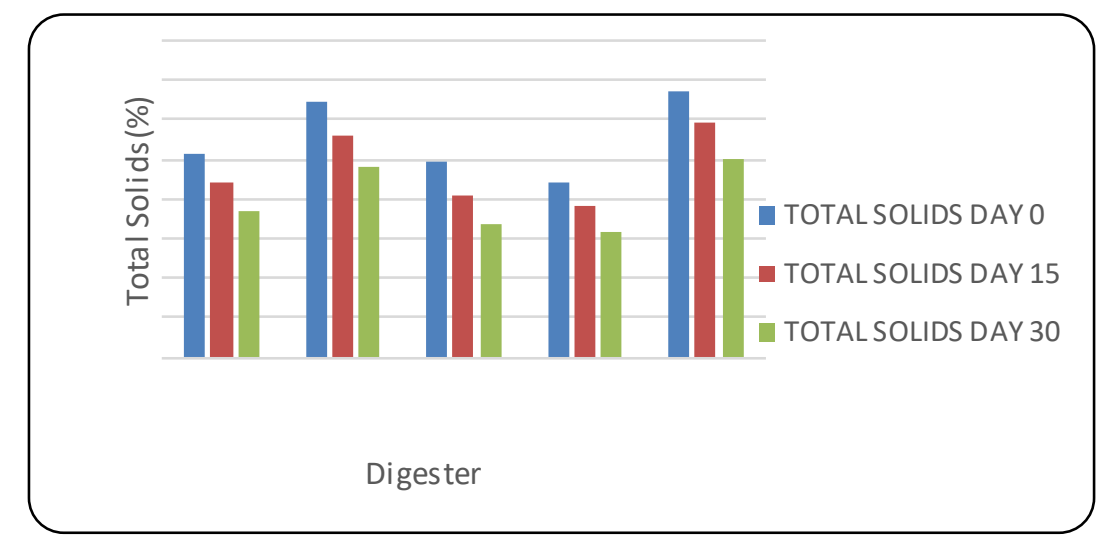

Fig.2: Weekly Total Solids

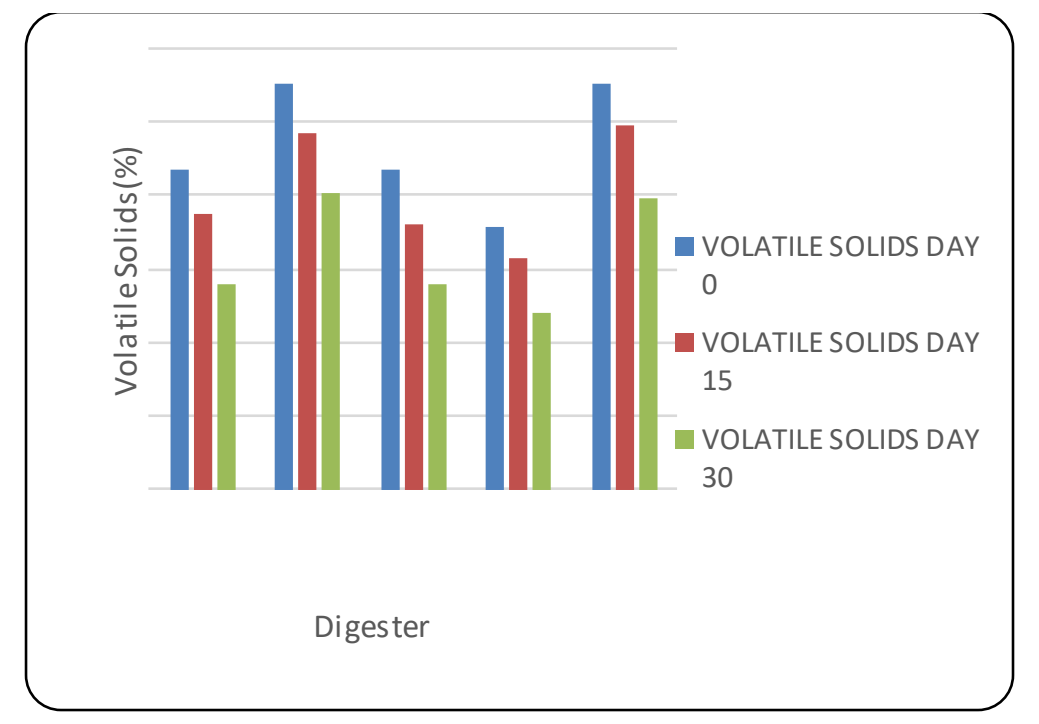

Fig.3: Weekly Volatile Solids 


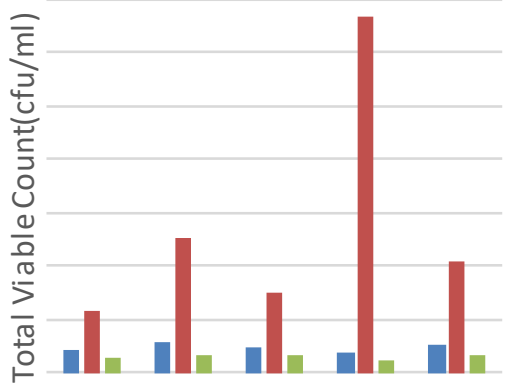

Digester
TOTAL VIABLE COUNT DAY 0

- TOTAL VIABLE COUNT DAY 15

- TOTAL VIABLE COUNT DAY 30

Fig.4: Weekly Total Viable Count

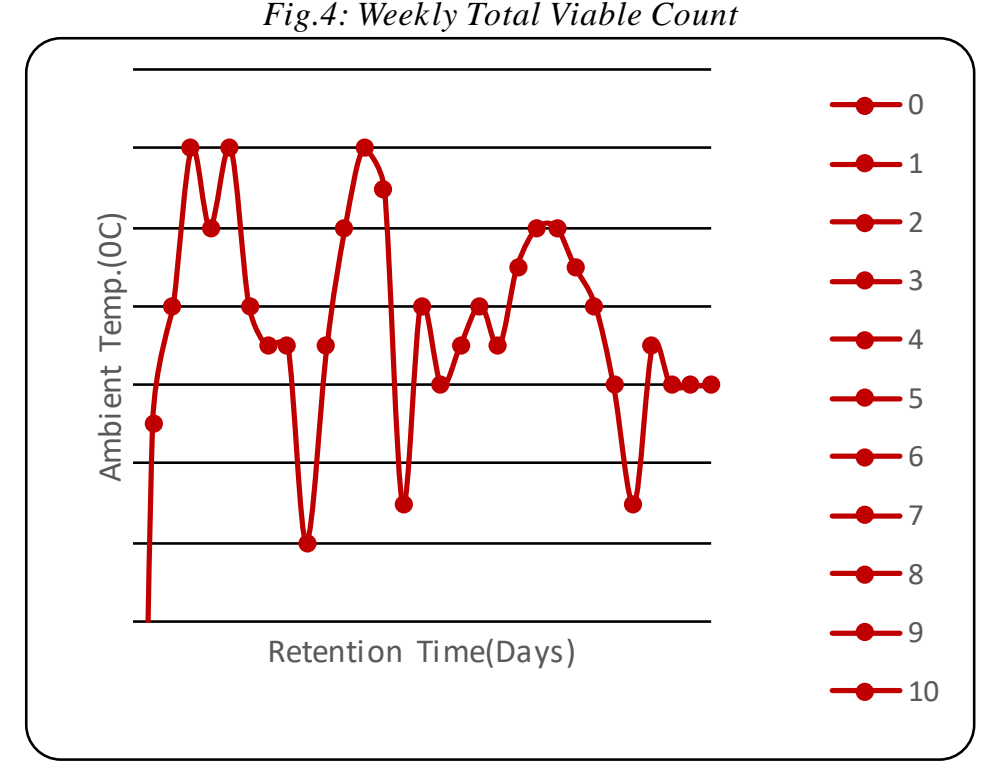

Fig.5: Ambient Temperature versus Retention Time

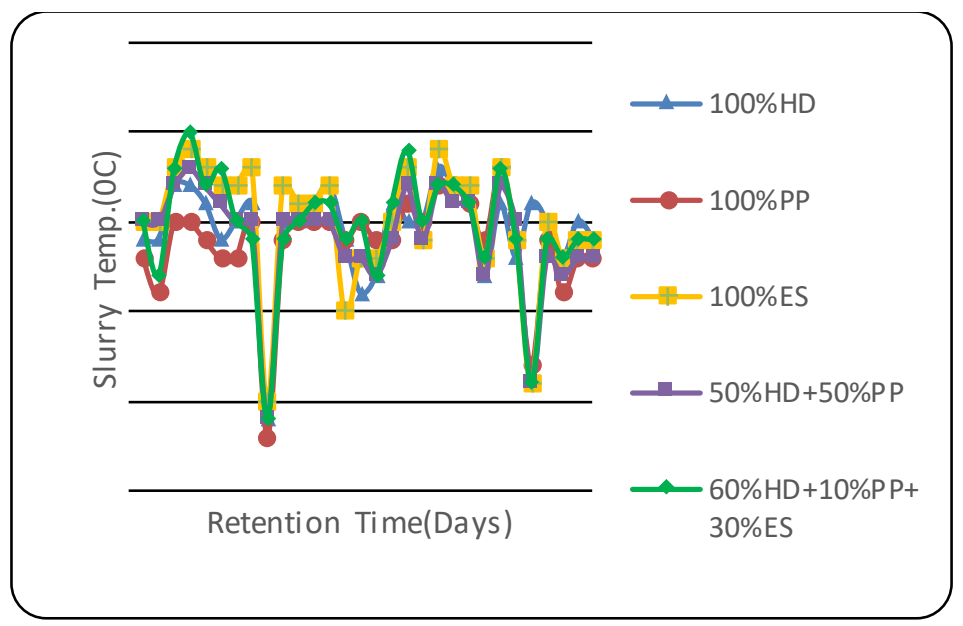

Fig.6: Slurry Temperature versus Retention Time 


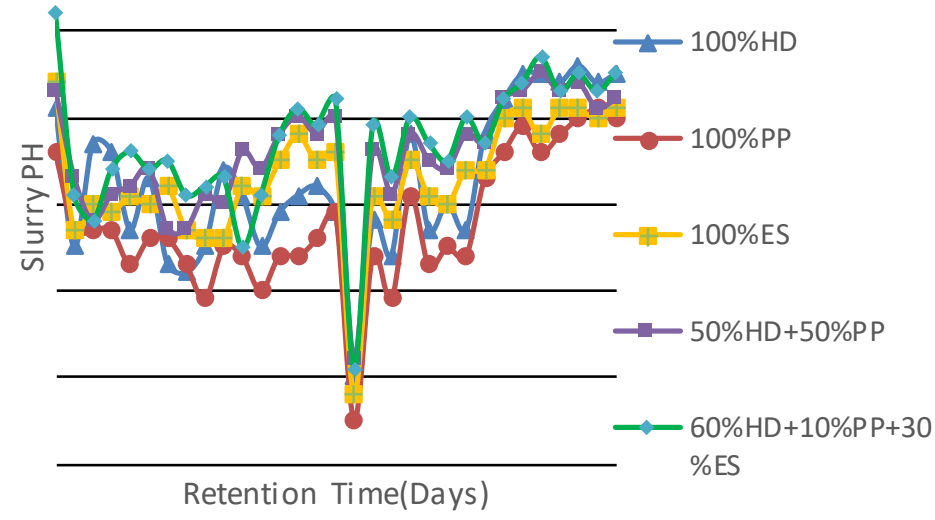

Fig.7: Slurry pH verus Retention Time

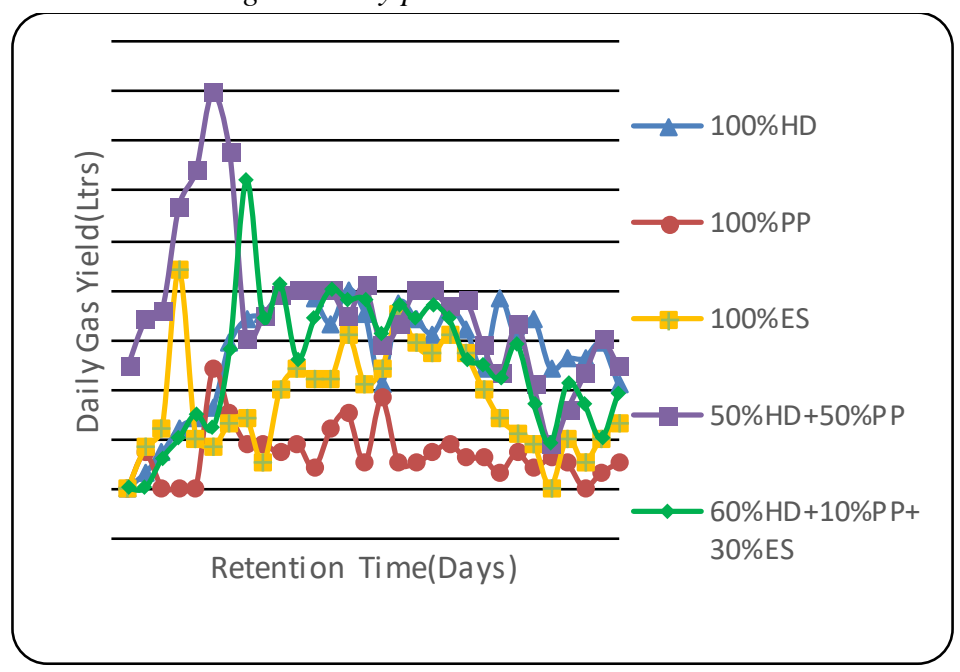

Fig.8: Daily Gas Yield versus Retention Time

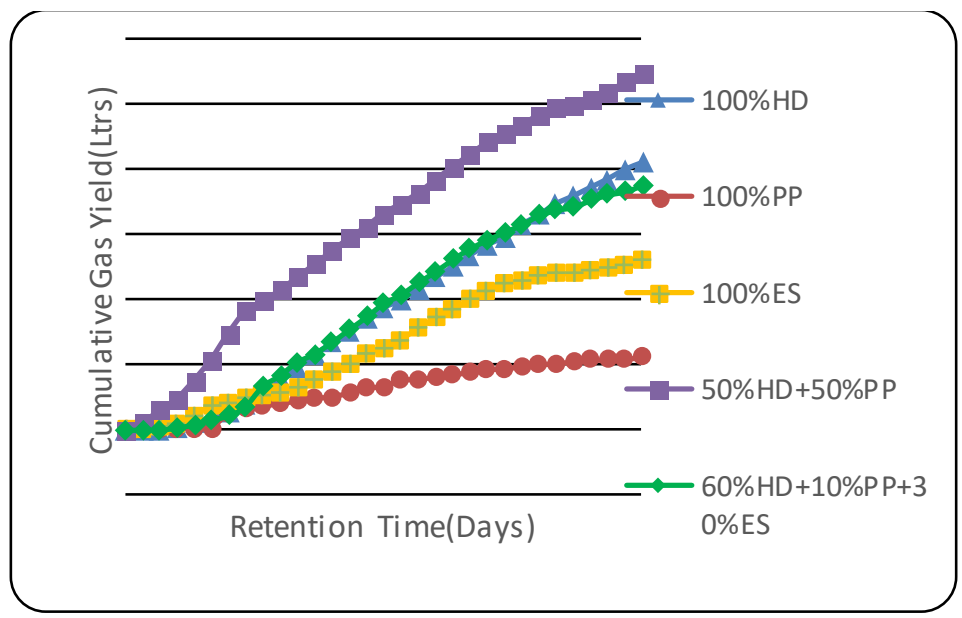

Fig.9: Cumulative Gas Yield versus Retention Time 


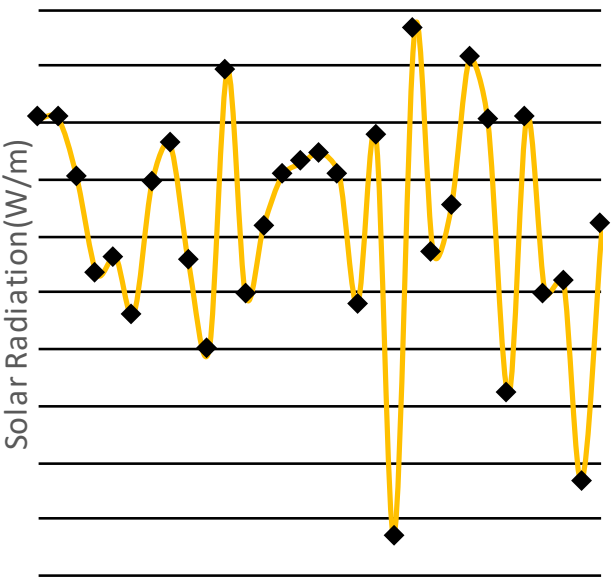

Retention Time(Days) $\bullet 0$

$\bullet 1$

$\bullet 2$

$\longrightarrow 3$

$\longrightarrow 4$

$\longrightarrow 5$

$-6$

$-7$

$\bullet 8$

$\bullet 9$

$\bullet-10$

Fig.10: Solar Radiation versus Retention Time

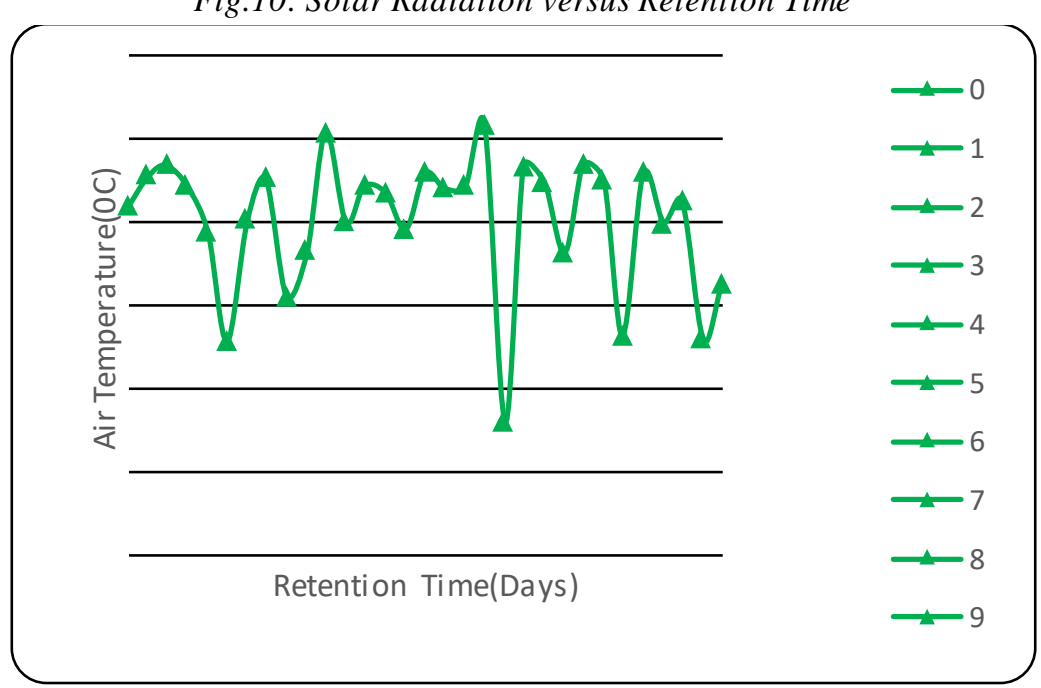

Fig.11: Air Temperature versus Retention Time

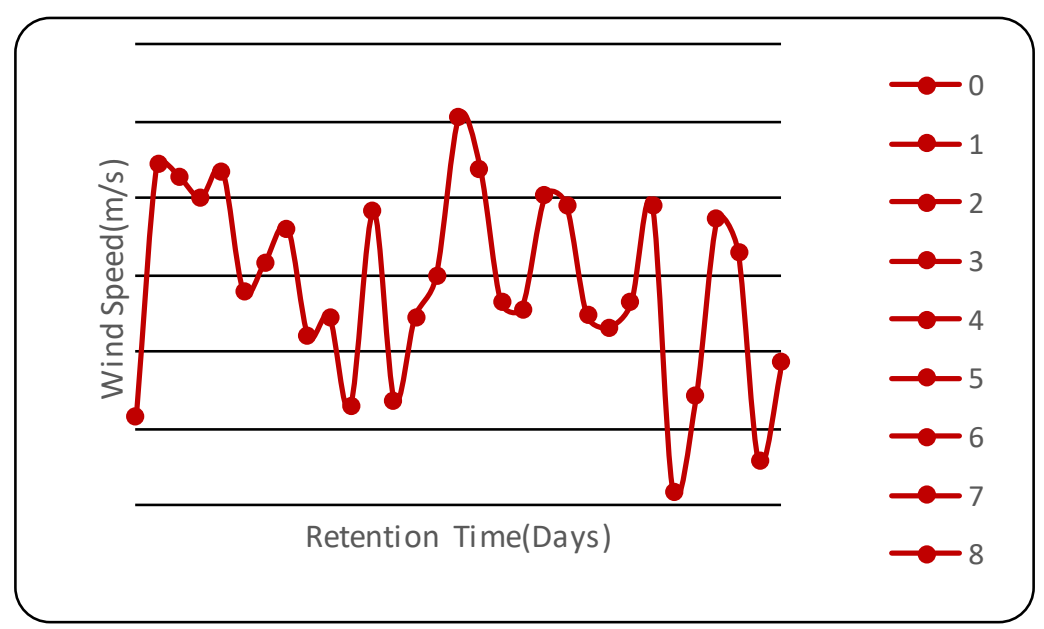

Fig.12: Wind Speed versus Retention Time 


\section{DIGESTERS' PERFORMANCE}

The results of digester performances (from Table 3) indicated that $100 \%$ HD system flamed on the 10th day; $100 \%$ PP system flamed on the $13^{\text {th }}$ day; $100 \%$ ES system flamed on the $16^{\text {th }}$ day, $50 \% \mathrm{HD}+50 \%$ PP system flamed on the 6 day while $60 \% \mathrm{HD}+30 \% \mathrm{ES}+10 \% \mathrm{PP}$ system famed on the $10^{\text {th }}$ day. By having lesser number of lag days, the $50 \% \mathrm{HD}+50 \%$ PP system is better in biogas production technology (Nagamani and Ramasamy, 1999). The cumulative gas yield from the five treatments were different: the $50 \% \mathrm{HD}+50 \% \mathrm{PP}$ had the highest cumulative gas yield (109L); followed by $100 \% \mathrm{HD}$ system (81.8L); $60 \% \mathrm{HD}+30 \% \mathrm{ES}+10 \% \mathrm{PP}$ system (75.2L); 100\% ES system (51.9L) and $100 \% \mathrm{PP}$ system (22.3L) during the 30 days retention period. $100 \% \mathrm{ES}$ system had the highest methane content $(90.3995 \%)$; followed by $60 \% \mathrm{HD}+30 \% \mathrm{ES}+10 \% \mathrm{PP}$ system $(87.3992 \%) ; 50 \% \mathrm{HD}+50 \%$ PP system $(82.5992 \%)$; $100 \% \mathrm{HD}$ system (79.999\%) and 100\%PP system (79.9963\%).

\section{EFFECT OF C/N RATIO ON THE SYSTEMS}

From the results of table 1 , the $\mathrm{C} / \mathrm{N}$ ratio of $100 \% \mathrm{HD}$, $100 \% \quad \mathrm{PP}, \quad 100 \% \mathrm{ES}, \quad 50 \% \mathrm{HD}+50 \% \mathrm{PP}$ and $60 \% \mathrm{HD}+30 \% \mathrm{ES}+10 \% \mathrm{PP}$ were seen to be within the range of optimum $\mathrm{C} / \mathrm{N}$ ratio. Consequently all the digester systems flamed. $\mathrm{C} / \mathrm{N}$ ratio is an important indicator for controlling biological systems. During anaerobic digestion, microorganisms utilize carbon 25 to 30 times faster than nitrogen (Yadvika et al., 2004). To meet these requirements, microbes need 20 to $30: 1$ ratio of $\mathrm{C}$ to $\mathrm{N}$.

\section{CALORIFIC VALUES OF SUBSTRATES}

The energy contents (table 4) show that the substrates are good feedstock for biogas production if properly utilized.Horse dung had the highest calorific value, followed by plantain peel and then eggshell.

\section{EFFECT OF WEEKLY TOTAL SOLIDS AND VOLATILE SOLIDS}

Total solid shows the total solid matter constituent of the entire organic waste both degradable and non-degradable. The volatile solid is the true organic matter available for bacterial action during digestion. There was generally a reduction in the weekly trend for total solids and volatile solids for each of the systems (figures 2 and 3).

\section{EFFECT OF WEEKLY BOD AND TOTAL VIABLE COUNT}

Biochemical Oxygen Demand (BOD) is the amount of dissolved oxygen needed (i.e. demanded) by aerobic biological organisms to breakdown organic materials present in a given water sample at certain temperature over a specific time period. This is a quantitative expression of the ability of microbes to deplete the oxygen in waste water. It is also the amount of oxygen required for the biological decomposition of organic matter in wastewater by bacteria under aerobic conditions. This depletion is caused by the microbes consuming organic matter in the water via aerobic respiration. Total Viable Count (TVC) gives a quantitative idea about the presence of microorganisms such as bacteria, yeast and mould in a sample. The count actually represents the number of colony forming units (cfu) per gram (or per $\mathrm{ml}$ ) of the sample. The BOD and TVC on 0-day were lower than those on the $15^{\text {th }}$ day since the microbes needed to acclimatize with the environment because there was no seeding. However, the values of BOD and TVC for the $30^{\text {th }}$ day were lower than those of the $15^{\text {th }}$ day; indicating stabilization. These trends were generally observed for each of the digester systems (figures 1 and 4).

\section{THE EFFECTS OF SOLAR RADIATION, WIND SPEED AND AIR TEMPERATURE}

There was variation in solar radiation resulting to highest solar radiation $(582.604 \mathrm{~W} / \mathrm{m})$ on the $20^{\text {th }}$ day and least $(135.655 \mathrm{~W} / \mathrm{m})$ on the $19^{\text {th }}$ day. Air temperature had highest $\left(30.309^{\circ} \mathrm{C}\right)$ on the $18^{\text {th }}$ day and least $\left(23.196^{\circ} \mathrm{C}\right)$ on the $19^{\text {th }}$ day. Wind speed had highest $(1.813 \mathrm{~m} / \mathrm{s})$ on the $15^{\text {th }}$ day and least $(0.84 \mathrm{~m} / \mathrm{s})$ on the $25^{\text {th }}$ day (figures 10,11 and 12$)$. The variation in these climatic conditions gave rise to variations in ambient temperature, slurry temperature, $\mathrm{pH}$, and daily volume of gas produced (figures 5, 6, 7 and 8).

\section{CONCLUSION}

This study has shown that wastes such as horse dung, plantain peel and egg shellwhich have been termed nuisance to the environment can be utilized to produce biogas which can be used as an alternative to the widely known and used fossil fuel. The digestate after biogas has been produced can also be used as fertilizer to improve plant growth and enhance soil capability in producing.

From the results, it can be seen that the three substrates and their combinations are excellent in producing flammable biogas; capable of being utilized for any purpose such as cooking. The research has shown that even though egg shell had the lowest calorific value; it had the highest methane content. 50\% HD+50\% PP had the least lag time (6 days).

This study has shown a new source for wealth creation and at the same time a means of decontaminating the environment by waste recycling and transformation. This wastes that are consumed in large quantities in homes can 
be used to produce biogas, this will help them lose the name attached to them as being nuis ance to the environment.

\section{RECOMMENDATIONS}

The following has been recommended as a result of findings from this work:

- The gas produced should be further purified to enhance its scope of utilization such as in welding and automobiles.

- A method of gas collection which is safe and highly reliable should be enhanced.

- Highly advanced technological equipment should be constructed for the storing the gas separately from the digesters.

- Equipment that can purify and utilize the biogas that has been produced can be fabricated; this will encourage people to use biogas.

- Researches should be carried out to discover means of improving the methane quality produced and also the quality of the bio-fertilizer left after digestion.

\section{REFERENCES}

[1] Association of Official Analysis of Chemist (A.O.A.C.), (1990).Standard Official Methods of Analysis.15th ed., Washington D.C.

[2] EPA. 2012. Increasing anaerobic digester performance with codigestion. AgStar Report. United States Environmental Protection Agency

[3] Ezekoye, V. A. (2013). A comparative study of biogas production using plantain/almond leaves and pig dung, and its applications. International Journal of Physical Sciences. 8(23):1291-1297.

[4] Hadin $\mathrm{S}^{1}$, Eriksson $\mathrm{O}^{2}$. Horse manure as feedstock for anaerobic digestion. Waste Manag. 2016 Oct;56:50618. doi: 10.1016/j.wasman.2016.06.023. Epub 2016 Jul 7.

[5] Külling, D.R., Menzi, H., Dohme, F., Sutter, F., Lischer, P., Kreuzer, M. (2002).Methane emissions of differently fed dairy cows and corresponding methane and nitrogen emissions from their manure during storage. Environmental Monitoring and Assessment, 79: $129-150$.

[6] Kusch $\mathrm{S}^{1}$, Oechsner $\mathrm{H}$, Jungbluth $\mathrm{T}$. Biogas production with horse dung in solid-phase digestion systems.Bioresour Technol. 2008 Mar;99(5):1280-92. Epub 2007 Mar 26.

[7] Lantz, M., Svensson, M., Björnsson, L., Börjesson, P. (2007). The prospects for an expansion of biogas systems in Sweden: Incentives, barriers and potential. Energy policy, 35:1830-1843.
[8] Lassey, K. (2008). Livestock methane emission and its perspective in the global methane cycle. Australian Journal of Experimental Agriculture, 48:114-118.

[9] Meynell, P. J. (1982). Methane: Planning a Digester. Prism Press, Stable Court, Chatmington, Dovest.

[10] Nagamani, B. and K. Ramasamy (1999). Biogas Production Technology: An Indian Perspective. Current Science, 77(1): 44-55.

[11] Nwankwo, J. I. (2014). Production of Biogas from Plantain Peels and Swine Droppings.IOSR Journal of Pharmacy and Biological Sciences. 9: 50-60.

[12] Ofili I., Ibrahim A. H., Orban M. O., Abur F. F., Okpanachi A. I. (2010). Comparis on of Biogas Yield from Anaerobic Digestion of Rabbit Waste and Swine Dung.International Journal of Advanced Engineering Research and Science (IJAERS). Vol-2: 10. 23496495

[13] Pearson (1976).Chemical Composition and Analysis of Food.In The Chemical Analysis of Foods. Churchill Livingstone, New York. Pp. 429-431.

[14] Walkey Black (1934). A Standard Analytical Laboratory Techniques in the Department of soil Science, University of Nigeria, Nsukka.

[15] Yadvika.,Santosh., Sreekrishnan, T.R., Kohli, S., Rana, V. (2004). Enhancement of biogas production from solid substrates using different technique: Bioresource Technology, 95:1-10. 